\title{
Estrogen Mobilizes a Subset of Estrogen Receptor- $\alpha$ - Immunoreactive Vesicles in Inhibitory Presynaptic Boutons in Hippocampal CA1
}

\author{
Sharron A. Hart, Melissa A. Snyder, Tereza Smejkalova, and Catherine S. Woolley \\ Department of Neurobiology and Physiology, Northwestern University, Evanston, Illinois 60208
}

\begin{abstract}
Although the classical mechanism of estrogen action involves activation of nuclear transcription factor receptors, estrogen also has acute effects on neuronal signaling that occur too rapidly to involve gene expression. These rapid effects are likely to be mediated by extranuclear estrogen receptors associated with the plasma membrane and/or cytoplasmic organelles. Here we used a combination of serialsection electron microscopic immunocytochemistry, immunofluorescence, and Western blotting to show that estrogen receptor- $\alpha$ is associated with clusters of vesicles in perisomatic inhibitory boutons in hippocampal CA1 and that estrogen treatment mobilizes these vesicle clusters toward synapses. Estrogen receptor- $\alpha$ is present in approximately one-third of perisomatic inhibitory boutons, and specifically in those that express cholecystokinin, not parvalbumin. We also found a high degree of extranuclear estrogen receptor- $\alpha$ colocalization with neuropeptide Y. Our results suggest a novel mode of estrogen action in which a subset of vesicles within a specific population of inhibitory boutons responds directly to estrogen by moving toward synapses. The mobilization of these vesicles may influence acute effects of estrogen mediated by estrogen receptor- $\alpha$ signaling at inhibitory synapses.
\end{abstract}

Key words: glutamic acid decarboxylase; GABAergic; cholecystokinin; parvalbumin; neuropeptide Y; serial-section electron microscopy

\section{Introduction}

The classical mechanism of estrogen action involves activation of nuclear transcription factor receptors, estrogen receptor- $\alpha$ $(\mathrm{ER} \alpha)$ (Greene et al., 1986; Koike et al., 1987) and/or ER $\beta$ (Kuiper et al., 1996), and subsequent regulation of gene expression. However, estrogens also exert acute effects on synaptic physiology that occur too rapidly to involve changes in gene expression (Teyler et al., 1980; Wong and Moss, 1992; Rudick and Woolley, 2003). These rapid effects have been attributed variously to extranuclear ER $\alpha / \mathrm{ER} \beta$ or to novel ERs (Qiu et al., 2006). The ER(s) mediating the rapid effects of estrogen could be located at the plasma membrane and/or in cytoplasmic compartments. Some studies have reported extranuclear immunoreactivity for ER $\alpha$ (Blaustein et al., 1992; Milner et al., 2001) or ER $\beta$ (Mitra et al., 2003) in dendrites, axons, and glia in the hypothalamus and hippocampus. However, these studies are primarily qualitative, and little is known about how extranuclear ERs might influence neuronal function.

The dorsal CA1 region of the hippocampus is a likely site for extranuclear ER action. Estrogen has profound effects on synaptic structure and function in CA1, yet few neurons in this region

Received Dec. 11, 2005; revised Jan. 21, 2007; accepted Jan. 22, 2007.

This work was supported by National Institute of Neurological Disorders and Stroke Grant NS37324, The W. M. Keck Foundation, and National Center for Research Resources Grant RR015497. We acknowledge Renee May for expert technical assistance and the support of the Northwestern University Biological Imaging Facility.

Correspondence should be addressed to Dr. Catherine S. Woolley, Northwestern University, 2205 Tech Drive, Evanston, IL 60208. E-mail: cwoolley@northwestern.edu.

D01:10.1523/JNEUROSCI.5436-06.2007

Copyright $\odot 2007$ Society for Neuroscience $\quad$ 0270-6474/07/272102-10\$15.00/0 express a nuclear ER (Hart et al., 2001; Blurton-Jones and Tuszynski, 2002; Mitra et al., 2003). Estrogen increases dendritic spine and excitatory synapse numbers in CA1 (Woolley and McEwen, 1992; Adams et al., 2001), increases the sensitivity of CA1 pyramidal cells to excitatory synaptic input (Woolley et al., 1997; Rudick and Woolley, 2001), and increases dorsal hippocampal seizure susceptibility (Terasawa and Timiras, 1968). Both in vitro (Murphy et al., 1998) and in vivo (Rudick and Woolley, 2001; Rudick et al., 2003) studies suggest that estrogen regulates excitatory synaptic connectivity through an initial suppression of inhibitory GABAergic synaptic transmission. Consistent with a direct effect of estrogen on GABAergic neurons, nearly all of the neurons in dorsal CA1 that express a nuclear ER are GABAergic (Hart et al., 2001). These cells express ER $\alpha$; although some CA1 cells express ER $\beta$ mRNA (Shughrue et al., 1997), there is little evidence for $\mathrm{ER} \beta$ protein in CA1 (Blurton-Jones and Tuszynski, 2002; Mitra et al., 2003). However, despite the fact that nuclear $\mathrm{ER} \alpha$ in dorsal CA1 is limited to GABAergic neurons, only $5-14 \%$ of these neurons express ER $\alpha$ (Hart et al., 2001). Thus, it appears that too few cells express a nuclear ER to account entirely for the widespread effects of estrogen on CA1 synapses.

In addition to the few ER $\alpha$-positive nuclei in CA1, there is substantial $\mathrm{ER} \alpha$ immunoreactivity (IR) in the neuropil of this region. Because extranuclear $\operatorname{ER} \alpha$-IR is particularly distinct in the cell body layer, we hypothesized that $\mathrm{ER} \alpha$ might be present in axonal boutons of GABAergic basket cells that form perisomatic synapses with CA1 pyramidal cells. Here we used serial-section electron microscopic immunocytochemistry and immunofluorescence to show that clusters of vesicles within a specific neuro- 
chemical subpopulation of inhibitory boutons are $\mathrm{ER} \alpha$ immunoreactive and that estrogen treatment shifts the location of $\operatorname{ER} \alpha-$ immunoreactive vesicle clusters toward synapses. These findings demonstrate a novel mode of estrogen action on presynaptic vesicles.

\section{Materials and Methods}

Animals. All animal procedures were performed in accordance with the National Institutes of Health Guide for the Care and Use of Laboratory Animals and were approved by the Northwestern University Institutional Animal Care and Use Committee. Twenty adult, female Sprague Dawley rats $[\sim 250 \mathrm{~g} ; 10$ for bright-field microscopy and electron microscopy (EM), and 10 for immunofluorescence; Harlan, Indianapolis, IN] were ovariectomized under ketamine $(85 \mathrm{mg} / \mathrm{kg}) /$ xylazine $(13 \mathrm{mg} / \mathrm{kg}$, i.p.) anesthesia and $3 \mathrm{~d}$ later were given subcutaneous injections of $10 \mu \mathrm{g}$ of $17 \beta$-estradiol benzoate or oil vehicle as described previously (Rudick and Woolley, 2001; Ledoux and Woolley, 2005). Twenty-four hours after injection, animals were deeply anesthetized with sodium pentobarbital $(80 \mathrm{mg} / \mathrm{kg}$, i.p.) and perfused either with $2 \%$ paraformaldehyde $/ 2 \%$ glutaraldehyde in $0.1 \mathrm{M}$ phosphate buffer (PB) for immunolabeling with diaminobenzidine (DAB; Sigma, St. Louis, MO) or with $4 \%$ paraformaldehyde in PB for immunofluorescence. Additional adult female rats ( $\sim 250$ g; Harlan) were perfused with $2 \%$ paraformaldehyde/2\% glutaraldehyde in PB for immunolabeling with silver-enhanced nanogold particles (Nanoprobes, Yaphank, NY) or with buffer containing protease inhibitors for Western blots. The efficacy of estradiol treatment was verified by visual assessment of the uterus at the time of perfusion.

Immunolabeling for bright-field microscopy and EM. Immunostaining for $\mathrm{ER} \alpha$ was as described previously (Hart et al., 2001). Briefly, perfusion-fixed brains were removed, blocked to contain the hippocampus, postfixed overnight at $4^{\circ} \mathrm{C}$, cryoprotected with $30 \%$ sucrose, and sectioned (50 or $100 \mu \mathrm{m}$ ), using an SM $2000 \mathrm{R}$ freezing microtome (Leica, Bannockburn, IL), into coronal sections spanning the dorsal hippocampus. To increase antigenicity, tissue was preincubated in $10 \%$ sodium borohydride (Sigma) before processing (Leenen et al., 1985). For visualization with $\mathrm{DAB}$, alternating sections were labeled with rabbit polyclonal MC-20 (0.5 $\mu \mathrm{g} / \mathrm{ml}$; Santa Cruz Biotechnology, Santa Cruz, CA) or mouse monoclonal 6F11 (1:50; Novocastra, Newcastle, UK), followed by species-specific biotinylated IgG (1:800; Vector Laboratories, Burlingame, $\mathrm{CA}$ ), and visualized with $\mathrm{DAB}$ using an $\mathrm{ABC}$ kit (Vector Laboratories). Neither MC-20 (Azcoitia et al., 1999) nor 6F11 (Bevitt et al., 1997) cross-reacts with ER $\beta$. Some sections were then dehydrated, cleared, and coverslipped under Eukitt for bright-field evaluation of nuclear and exatranuclear labeling. The remaining sections were stained with osmium tetroxide and flat embedded in Eponate resin (Ted Pella, Redding, CA) for EM. For each brain, $200-230$ serial thin sections $(\sim 70$ $\mathrm{nm}$ ) were cut on a Reichert Ultracut S ultramicrotome (Leica), collected on formvar-coated slot grids, and stained with uranyl acetate and lead citrate (Ted Pella). Brains were coded before sectioning so that the experimenter was blind to the treatment condition during all phases of image collection, three-dimensional reconstruction, and analysis.

Additional animals were used for MC-20 immunolabeling visualized with silver-enhanced nanogold particles. Tissue was processed identically to that above, except that the primary incubation was followed by nanogold-coupled IgG (1:50) and HQ-silver reagent (Nanoprobes). Sections were then stained with osmium tetroxide and flat embedded in Eponate resin (Ted Pella) for thin sectioning. Short series of thin sections $(\sim 70 \mathrm{~nm})$ were cut and, as above, collected on formvar-coated slot grids and stained with uranyl acetate and lead citrate.

Quantification of ER $\alpha$-immunoreactive nuclei. The numbers of ER $\alpha$ immunoreactive nuclei in the dorsal subiculum, CA1, CA3, and dentate gyrus subregions were estimated using the optical disector/fractionator (West et al., 1991) as described by Hart et al. (2001). Tissue was visualized on an Olympus (Tokyo, Japan) BX60 microscope equipped with a Dage (Michigan City, IN) DC330 camera and ImagePro Plus software (Media Cybernetics, Silver Spring, MD). Briefly, a grid consisting of squares (353 $\mu \mathrm{m}^{2}$ ) was superimposed random-systematically over a lowmagnification image of every fifth section through the dorsal hippocam- pus. Each square contained an identically placed counting frame that was $1 / 16$ th the area of the square. When any part of the hippocampus was contained within the counting frame, the number of labeled nuclei within the frame was counted. The most intensely labeled nuclei generally were observed in conjunction with lighter cytoplasmic labeling in the soma and most proximal dendrites. Counts were made with a $100 \times$ oil-immersion lens starting $3 \mu \mathrm{m}$ below the surface and continuing in 0.5 $\mu \mathrm{m}$ steps though a depth of $13 \mu \mathrm{m}$. The total number of cells was then estimated using the following formula: \# cells $=\Sigma Q^{-}(t / h)(1 /$ asf $)(1 / s s f)$, where $Q^{-}$is the total number of cells counted, $t$ is the section thickness $(50 \mu \mathrm{m}), h$ is the height of the disector $(10 \mu \mathrm{m})$, asf is the area sampling fraction (1/16), and $s s f$ is the section sampling fraction (1/5).

Three-dimensional EM reconstruction. The dorsal CA1 pyramidal cell layer was imaged using a JEOL (Peabody, MA) 100CX electron microscope. In tissue labeled with MC-20 visualized with DAB, five areas, each containing an $\mathrm{ER} \alpha$-immunoreactive perisomatic bouton, were identified in a section near the middle of each set of serial thin sections. Negatives of these five areas were taken at 10,000 $\times$ from the middle section and from 40 to 50 serial sections on both sides (five stacks of $80-100$ serial negatives per brain). Negatives were scanned at 1600 dpi and aligned with SEM Align software (courtesy of K. M. Harris, University of Texas, Austin, TX, and J. C. Fiala, Boston University, Boston, MA). The plasma membrane, synaptic densities, and mitochondria were traced and reconstructed using IGL Trace software (courtesy of K. M. Harris and J. C. Fiala). The location of each vesicle in a bouton was also marked. Measurements of volume, synaptic area, and numbers of vesicles for each bouton were generated using IGL Trace. The distance between each vesicle and synapse in a bouton was measured using Reconstruct software (courtesy of K. M. Harris and J. C. Fiala) and converted into a measurement of relative distance, with 1.0 being the maximum distance from the synapse that a vesicle could be. For boutons with more than one synapse, the synapse nearest to the $\mathrm{ER} \alpha$-immunoreactive vesicle cluster was used for the relative distance measure.

Western blots. Western blots were used to confirm MC-20 specificity in dorsal CA1. Buffer-perfused brains were removed, blocked to contain the hippocampus, and sectioned (300 $\mu \mathrm{m})$, using an OTS 4000 oscillating tissue slicer (EMS, Hatfield, PA), into coronal sections spanning the rostrocaudal extent of the dorsal hippocampus. The CA1 region was dissected from these slices on ice and homogenized in ice-cold $20 \mathrm{~mm}$ PBS, pH 7.4, with 2 mM EGTA and 1 mm phenylmethylsulfonyl fluoride (PMSF). The homogenate was lysed with $1.5 \%$ Triton X-100, incubated on ice for $30 \mathrm{~min}$, and centrifuged at 15,000 $\times g$ for $20 \mathrm{~min}$. The supernatant was collected as the whole-cell fraction and kept frozen at $-80^{\circ} \mathrm{C}$ until use.

Western blots were also used to confirm ER $\alpha$ in cytoplasmic, synaptosomal, and synaptic vesicle fractions isolated from the dorsal hippocampus by differential centrifugation (Huttner et al., 1983). For these experiments, rats were perfused with ice-cold homogenization buffer (320 mm sucrose, 4 mm HEPES-NaOH buffer, pH 7.4, 2 mm EGTA, 1 mm sodium orthovanadate, $0.1 \mathrm{~mm}$ PMSF, $50 \mathrm{~mm}$ sodium fluoride, $10 \mathrm{~mm}$ sodium pyrophosphate, $20 \mathrm{~mm}$ glycerophosphate, $1 \mu \mathrm{g} / \mathrm{ml}$ leupeptin, and $1 \mu \mathrm{g} / \mathrm{ml}$ aprotinin). The brains were rapidly removed, and all subsequent steps were performed at $4^{\circ} \mathrm{C}$. Dorsal hippocampi were dissected and homogenized, followed by centrifugation at $1000 \times g$ for $10 \mathrm{~min}$ to remove large cell fragments and nuclear material. The supernatant was centrifuged at $17,000 \times g$ for 15 min to yield cytoplasmic proteins in the supernatant. The pellet from this spin was resuspended in homogenization buffer and centrifuged at $17,000 \times g$ for an additional $15 \mathrm{~min}$ to yield washed synaptosomes. The synaptosomal fraction then was hypoosmotically lysed and centrifuged at $25,000 \times g$ for 20 min to yield synaptosomal plasma membranes and crude synaptic vesicles. Crude synaptic vesicles then were centrifuged at $160,000 \times g$ for $2 \mathrm{~h}$ to pellet the synaptic vesicle fraction. Cytoplasmic proteins, washed synaptosomes, and synaptic vesicle fractions were analyzed. For all Western blots, protein concentration was determined using the Bio-Rad (Hercules, CA) protein assay. The protein sample was mixed with Laemmli sample buffer (62.5 mм Tris-HCl, pH 6.8, 25\% glycerol, 2\% SDS, 0.01\% bromophenol blue, and $5 \% \beta$-mercaptoethanol), boiled for $5 \mathrm{~min}$, and separated on a $10 \%$ SDS-PAGE gel. After electrophoresis, proteins were 
transferred to polyvinylidene difluoride membranes (Millipore, Billerica, MA). The membrane was blocked in 5\% nonfat milk, probed for synaptophysin with MAB5258 (1:1,000,000; Chemicon, Temecula, CA) and/or ER $\alpha$ with MC-20 $(0.1 \mu \mathrm{g} / \mathrm{ml})$, followed by horseradish peroxidasecoupled anti-mouse (1:2000) or anti-rabbit (1:1000) IgG (Vector Laboratories), and visualized using enhanced chemiluminescence (ECL Plus; GE Healthcare, Piscataway, NJ).

Immunofluorescence. Perfusion-fixed brains were removed, blocked to contain the hippocampus, postfixed overnight at $4^{\circ} \mathrm{C}$, cryoprotected with $30 \%$ sucrose, and cut on a freezing microtome (Leica) into coronal sections $(40 \mu \mathrm{m})$ spanning the rostrocaudal extent of the dorsal hippocampus. Sections were systematically distributed into four groups double labeled for $\operatorname{ER} \alpha(0.1 \mu \mathrm{g} / \mathrm{ml}, \mathrm{MC}-20)$ and one of the following: mouse monoclonal glutamic acid decarboxylase 65 (GAD65) $(0.3 \mu \mathrm{g} / \mathrm{ml}$, MAB351; Chemicon), mouse monoclonal parvalbumin (PV) (1:8000, P3088; Sigma), rabbit polyclonal cholecystokinin (CCK) (1:1000, PC206L; Calbiochem, La Jolla, CA), or rabbit polyclonal neuropeptide Y (NPY) (1:4000, N9528; Sigma). Tissue processing was as described previously (Hart et al., 2001), except for visualization with species-specific IgG directly coupled to a fluorochrome. For ER $\alpha$ colocalization, ER $\alpha$-IR was visualized with Alexa Fluor 568, whereas GAD-, PV-, CCK-, and NPY-IRs were visualized with Alexa Fluor 488 (each $2.5 \mu \mathrm{g} / \mathrm{ml}$; Invitrogen, San Diego, CA). For NPY colocalization with GAD, NPY-IR was visualized with Alexa Fluor 568, whereas GAD-IR was visualized with Alexa Fluor 488. Incubations were simultaneous in cases in which primaries were raised in different species (ER $\alpha$ and GAD or PV); controls included omission of primary antiserum or antibody. Incubations were sequential in cases in which primaries were raised in the same species (ER $\alpha$ and CCK or NPY). In these cases, a second blocking step was included after the first secondary incubation, and some tissue was processed with the second primary antiserum omitted as an additional control. In these controls, no labeling of the first primary antiserum with the second secondary antiserum was detected. All sections were mounted in order on subbed slides, dehydrated, cleared, rehydrated, coverslipped under Vectashield (Vector Laboratories), and sealed with nail polish.

Slides were coded before image collection, so the experimenter was blind to the treatment condition of each brain during all phases of image collection and analysis. Tissue was imaged using a spinning disc laser confocal system (PerkinElmer, Wellesley, MA) with a $100 \times$ oil objective. For each brain, three image stacks in each hemisphere were collected from three sections in each brain, for a total of 18 stacks per brain. The volume of each stack was $21,600 \mu \mathrm{m}^{3}$ (ER $\alpha$ and GAD or PV) or 10,800 $\mu \mathrm{m}^{3}$ (ER $\alpha$ and CCK or NPY) and consisted of a $70 \times 70 \mu \mathrm{m}$ image field taken at $0.2 \mu \mathrm{m}$ z-steps with the CA1 pyramidal cell layer in the center of the field. Quantification of immunofluorescence and colocalization were performed using Volocity software (Improvision, Lexington, MA).

Statistics. Cumulative histograms of relative distances were generated for oil and estradiol treatment groups and compared using the Kolmogorov-Smirnov (K-S) test $\left(D_{\max }=0.163\right.$ for $\left.p<0.01 ; n=100\right)$. The mean relative distance of $\mathrm{ER} \alpha$-immunoreactive vesicles and means for measures of basic structural characteristics of boutons as well as fluorescence and colocalization were calculated for each brain, and treatment groups were compared using Student's $t$ test (unpaired, two-tailed; $n=4$ ) using SPSS (Chicago, IL) software.

Data display. All figures were prepared with Photoshop (Adobe Systems, San Jose, CA). Graphs and histograms were plotted using SigmaPlot (SPSS). Bouton reconstruction files were imported into and rendered with 3D StudioMax (Autodesk, San Raphael, CA).

\section{Results}

Nuclear and extranuclear ER $\alpha$-IR

We confirmed nuclear and extranuclear $\operatorname{ER} \alpha$-IR in the dorsal CA1 cell body layer of adult female rats using MC-20, a polyclonal antiserum raised against the $\mathrm{C}$ terminus of mouse $\mathrm{ER} \alpha$ visualized with DAB. As described previously (Hart et al., 2001), nuclear $\mathrm{ER} \alpha$-IR was present in a relatively small proportion of cells located primarily in the dendritic layers; pyramidal cell nuclei were unlabeled (Fig. 1A). Extranuclear ER $\alpha$-immunoreactive puncta were

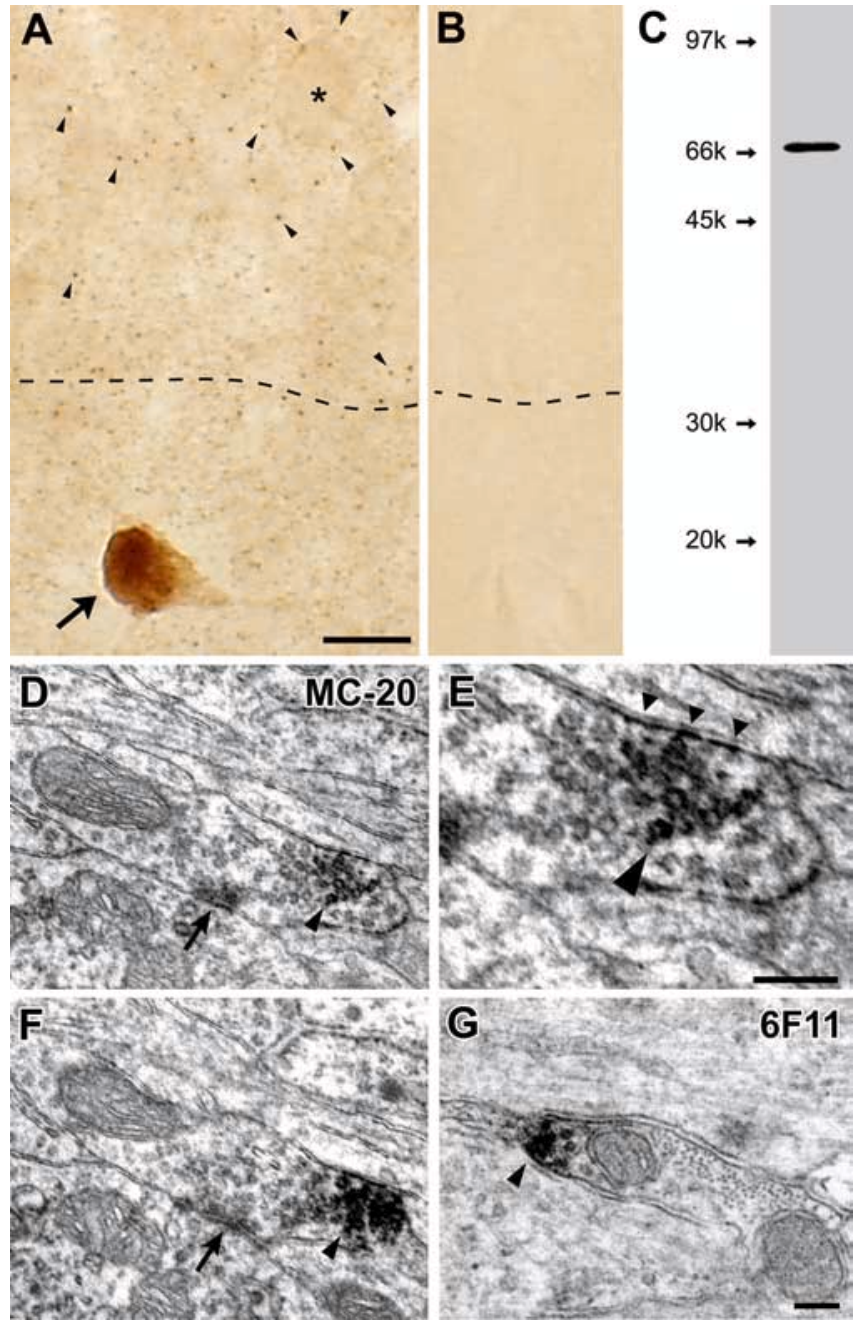

Figure 1. Extranuclear $E R \alpha$-IR in the dorsal CA1 cell body layer. $\boldsymbol{A}, \mathrm{ER} \alpha$-IR visualized with bright-field microscopy. The dashed line delineates the boundary of the cell body layer (above) and stratum radiatum (below). Extranuclear ER $\alpha$-immunoreactive puncta (small dark dots, some of which are indicated by arrowheads) are numerous and occasionally appear to ring unlabeled somata (asterisk). A cell with interneuron-like morphology located in the proximal stratum radiatum contains nuclear ER $\alpha$-IR (arrow). $\boldsymbol{B}$, High-magnification view of the same area from tissue processed with the primary antiserum omitted. No labeling is observed. $\boldsymbol{C}$, Western blot probed with MC-20, the antiserum used for quantification of $E R \alpha$-IR, showing a single band at $\sim 67 \mathrm{kDa}$. $D$, Electron micrograph of one of two consecutive sections showing MC-20 labeling for $E R \alpha$ on a portion of vesicles (arrowhead) located in a presynaptic bouton forming a symmetric synapse (arrow) with a CA1 pyramidal cell soma. Note that ER $\alpha$ immunoreactive vesicles appear to be clustered. $\boldsymbol{E}$, Higher magnification of the same section as in $\boldsymbol{D}$ shows $E R \alpha$-IR associated with vesicles (large arrowhead) and nearby on the bouton plasma membrane (small arrowheads). $\boldsymbol{F}$, The section adjacent to that in $\boldsymbol{D}$ shows the same ER $\alpha$ immunoreactive vesicle cluster. $\mathbf{G}$, ER $\alpha$ labeling with $6 \mathrm{~F} 11$ is qualitatively similar to labeling with MC-20, with $E R \alpha$-IR associated with vesicles and the bouton plasma membrane (arrowhead). Scale bars: $\boldsymbol{A}, \boldsymbol{B}, 10 \mu \mathrm{m} ; \boldsymbol{D}, \boldsymbol{F}, \boldsymbol{G}, 200 \mathrm{~nm} ; \boldsymbol{E}, 200 \mathrm{~nm}$.

observed throughout CA1 but were particularly distinct in the cell body layer and occasionally appeared to ring unlabeled pyramidal cell somata. This suggested that ER $\alpha$-IR might be contained within perisomatic axonal boutons of inhibitory basket cells, a question we addressed subsequently with EM. Both nuclear and extranuclear $\mathrm{ER} \alpha$ labeling were absent when the primary antiserum was eliminated (Fig. $1 B$ ) or when the antiserum was preadsorbed with blocking peptide (Hart et al., 2001). Western blots of whole-cell extracts from dorsal CA1 confirmed that the MC-20 antiserum recognized a single protein band at $\sim 67 \mathrm{kDa}$ (Fig. $1 C$ ), the predicted size of ER $\alpha$ in the rat (Koike et al., 1987). Qualitatively similar punctate ER $\alpha$-IR 
was also observed in tissue labeled with 6F11, a monoclonal antibody raised against full-length $\operatorname{ER} \alpha$ (data not shown).

We confirmed that, as reported previously for $72 \mathrm{~h}$ treatment (Hart et al., 2001), estrogen treatment for $24 \mathrm{~h}$ in vivo had no significant effect on the number of $\mathrm{ER} \alpha$-immunoreactive nuclei in any hippocampal subregion. We quantified ER $\alpha$ immunoreactive nuclei in the dorsal hippocampus of six ovariectomized oil-treated $(\mathrm{OVX}+\mathrm{O})$ and six ovariectomized, estrogen-treated $(\mathrm{OVX}+\mathrm{E})$ adult female rats using the optical disector/fractionator. The total numbers of ER $\alpha$ immunoreactive nuclei were as follows: in subiculum: $1850 \pm$ $507(\mathrm{OVX}+\mathrm{O})$ and $1100 \pm 73(\mathrm{OVX}+\mathrm{E})$; in CA1: $1566 \pm 286$ $(\mathrm{OVX}+\mathrm{O})$ and $917 \pm 70(\mathrm{OVX}+\mathrm{E})$; in CA3: $3567 \pm 724$ $(\mathrm{OVX}+\mathrm{O})$ and $2733 \pm 279(\mathrm{OVX}+\mathrm{E})$; in dentate gyrus: $2000 \pm$ $392(\mathrm{OVX}+\mathrm{O})$ and $1767 \pm 196(\mathrm{OVX}+\mathrm{E})$. All $p$ values were $>0.07$. Thus, in contrast to the effect of estrogen on hippocampal slice cultures, in which estrogen treatment for $8 \mathrm{~d}$ upregulates ER $\alpha$-IR (Rune et al., 2002), shorter treatments with estrogen in vivo do not appear to influence nuclear $\operatorname{ER} \alpha$ expression in the hippocampus.

Next, we used pre-embedding EM immunocytochemistry to investigate whether inhibitory axonal boutons in the CA1 cell body layer contain $\mathrm{ER} \alpha$-IR. We were especially interested in the possibility that $\mathrm{ER} \alpha$ is expressed in inhibitory boutons because we have shown previously that estrogen suppresses inhibitory GABAergic synaptic transmission in CA1 (Rudick and Woolley, 2001; Rudick et al., 2003). Inhibitory boutons were recognized as those that formed synapses with symmetric presynaptic and postsynaptic densities, $>95 \%$ of which are GABA immunoreactive in the CA1 cell body layer (Ledoux and Woolley, 2005). Electron imaging of tissue labeled for $\operatorname{ER} \alpha$ using either the MC-20 antiserum (Fig. 1D-F) or the 6F11 antibody (Fig. 1G) revealed that $\mathrm{ER} \alpha$-IR within inhibitory boutons was most often found associated with vesicles that appeared to be clustered. Occasionally, we also observed labeling on patches of the plasma membrane near $\mathrm{ER} \alpha$-immunoreactive vesicles. Additionally, small clumps of $\mathrm{ER} \alpha$-IR were present within pyramidal cell bodies, excitatory boutons, dendrites, and glia. The pattern of immunoreactivity was identical in tissue labeled with MC-20 compared with 6 F11.

We performed two additional analyses to confirm ER $\alpha$ associated with synaptic vesicles: EM immunocytochemistry with immunogold visualization and Western blot analysis of synaptic vesicle fractions. Evaluation of extranuclear ER $\alpha$-IR in the CA1 cell body layer visualized with immunogold showed the same pattern of labeling as observed with DAB. Gold particles were observed most frequently associated with vesicles in axonal boutons (1-5 particles) (Fig. 2A), dendritic spines (1-6 particles), and glia (1-10 particles); particles also were observed in neuronal nuclei and associated with somatic organelles. In some series, gold particles were observed in the same locations spanning consecutive sections.

Western blots of cell fractions probed with MC-20 (Fig. 2B) also confirmed that $\mathrm{ER} \alpha$ is associated with synaptic vesicles. Consistent with Western blots of whole-cell fractions, cytoplasmic protein fractions contained a single band at $\sim 67 \mathrm{kDa}$. Synaptophysin, a presynaptic vesicle protein, was present in relatively low levels in cytoplasmic fractions. Synaptophysin was concentrated in synaptosomes, as expected, but ER $\alpha$ did not represent a sufficient proportion of total synaptosomal protein to be detectable. However, $\mathrm{ER} \alpha$ was detectable in synaptic vesicle fractions derived from synaptosomes. Interestingly, ER $\alpha$ labeling in synaptic vesicle fractions consistently showed three bands. The major band
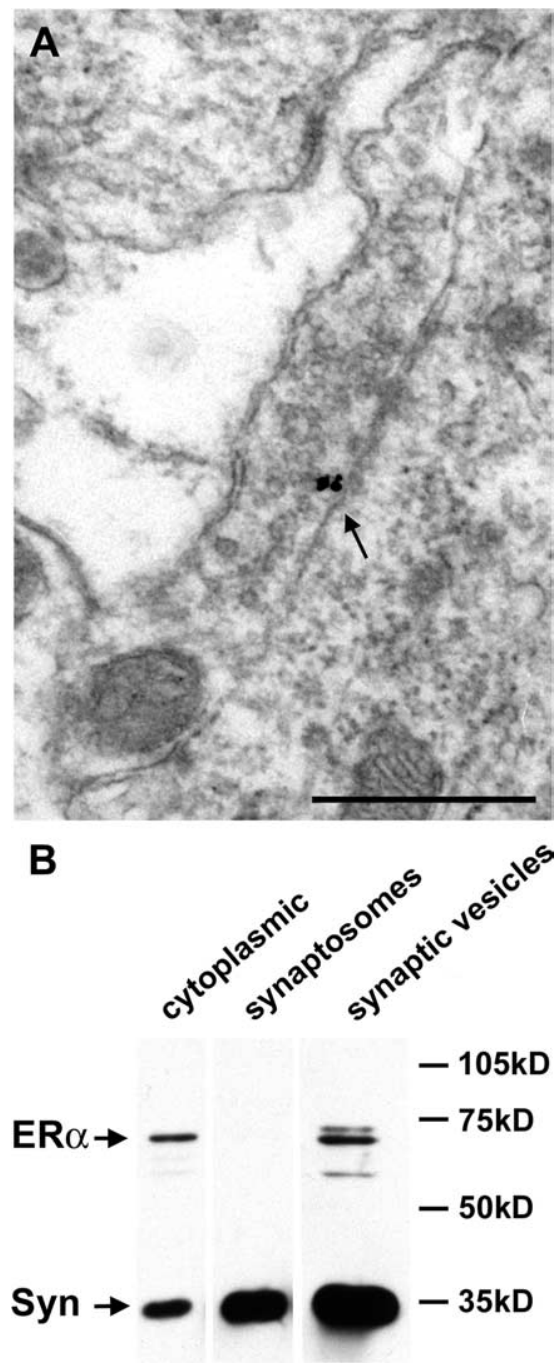

Figure 2. Immunogold and Western blot confirmation of $E R \alpha$-IR association with synaptic vesicles. $\boldsymbol{A}$, Electron micrograph of ER $\alpha$-IR visualized with immunogold (arrow) in a presynaptic bouton in the CA1 cell body layer. Scale bar, $500 \mathrm{~nm}$. B, A Western blot of cytoplasmic, synaptosomal, and synaptic vesicle proteins probed for synaptophysin (Syn) and $\operatorname{RR} \alpha$ shows that $E R \alpha$ is present in both cytoplasmic and synaptic vesicle fractions. Cytoplasmic fractions show a single band at $\sim 67 \mathrm{kDa}$, whereas synaptic vesicle fractions show a major band at $\sim 67 \mathrm{kDa}$ and two additional minor bands (see Results).

appeared at the expected $\sim 67 \mathrm{kDa}$, along with a slightly higher molecular weight band and a faint band at a lower molecular weight. The higher molecular weight band could represent ER $\alpha$ that has been post-translationally modified by phosphorylation or palmitoylation, which has been shown to promote its association with membranes (Acconcia et al., 2005). The identity of the lower molecular weight band is unknown.

\section{Colocalization of extranuclear ER $\alpha$-IR with GAD-IR}

Having shown that $\mathrm{ER} \alpha$-IR is contained within inhibitory axonal boutons where it is associated with vesicles, we next asked how many inhibitory boutons contain ER $\alpha$-IR. To investigate this question, we double labeled hippocampal tissue for $\operatorname{ER} \alpha$ and $\mathrm{GAD}$, the rate-limiting enzyme in GABA synthesis and a marker for inhibitory neurons; GAD antibodies label inhibitory axonal boutons intensely. We evaluated GAD-IR and ER $\alpha$-IR in five $\mathrm{OVX}+\mathrm{O}$ and five $\mathrm{OVX}+\mathrm{E}$ adult female rats. Projected images from stacks of optical sections showed characteristic GAD-IR in 
the cell body layer, with labeled varicosities arranged in rings around unlabeled pyramidal cell somata (Fig. 3A). For both GAD-IR and ER $\alpha$-IR, measurements of fluorescence intensity, volume, number of labeled objects, and percentage of colocalization were unaffected by estrogen, so data from both treatment groups were combined $(n=10)$. The lack of estrogen effect on extranuclear ER $\alpha$-IR mirrored the lack of effect on nuclear ER $\alpha$-IR. Quantitative analysis of 18 image stacks per brain $\left(21,600 \mu \mathrm{m}^{3}\right.$ per stack) showed that $32.4 \pm 0.6 \%$ of the $3815 \pm 141$ GADimmunoreactive varicosities per stack contained $\mathrm{ER} \alpha$-immunoreactive puncta (Fig. 3 B, C), and $24.0 \pm 0.5 \%$ of the $5549 \pm$ $187 \mathrm{ER} \alpha$-immunoreactive puncta per stack were located in GAD-immunoreactive varicosities (Fig. 3C). This analysis indicated that extranuclear $\mathrm{ER} \alpha$-IR is found in approximately one-third of GABAergic varicosities in the cell body layer but that a substantial fraction of punctate $\mathrm{ER} \alpha$-IR is located in non-GABAergic structures as well. The observation that not all $\operatorname{ER} \alpha$ immunoreactive puncta colocalize with GAD-immunoreactive varicosities is consistent with previous qualitative EM observations of $\mathrm{ER} \alpha$-IR in multiple extranuclear sites, such as dendrites, glia, excitatory axonal boutons, and somatic organelles (Milner et al., 2001).

\section{Serial EM reconstruction of axonal boutons containing $\mathrm{ER} \alpha$-IR}

Next, we used serial-section EM to generate three-dimensional reconstructions of axon segments containing $\mathrm{ER} \alpha$ immunoreactive vesicles to address three questions: (1) Does a single axon contain boutons both with and without $\mathrm{ER} \alpha$ immunoreactive vesicles? (2) Are boutons with $\mathrm{ER} \alpha$-immunoreactive vesicles structurally different from those without labeled vesicles? (3) Does estrogen treatment affect $\mathrm{ER} \alpha$-immunoreactive vesicles? We reconstructed axon segments containing $\mathrm{ER} \alpha$-IR visualized with DAB in tissue from each of eight rats, four OVX $+\mathrm{O}$ and four OVX $+\mathrm{E}$ (three to seven segments per rat). A total of 48 perisomatic inhibitory boutons from $\mathrm{ER} \alpha$-immunoreactive-containing axon segments were completely reconstructed and analyzed, as were 32 neighboring inhibitory boutons that synapsed with the same CA1 pyramidal cells. Examination of reconstructed boutons confirmed that, when present, $\mathrm{ER} \alpha$-immunoreactive vesicles were clustered but that clusters of labeled vesicles occur in only a subset of boutons on any single axon (Fig. 4). Thirty-three of the 80 boutons that we reconstructed contained $\mathrm{ER} \alpha$-immunoreactive vesicle clusters, roughly consistent with the GAD/ER $\alpha$ immunofluorescence colocalization analysis. In boutons containing labeled clusters, ER $\alpha$-immunoreactive vesicles accounted for $10.7 \pm 0.8 \%$ of all presynaptic vesicles, and the number of vesicles per cluster did
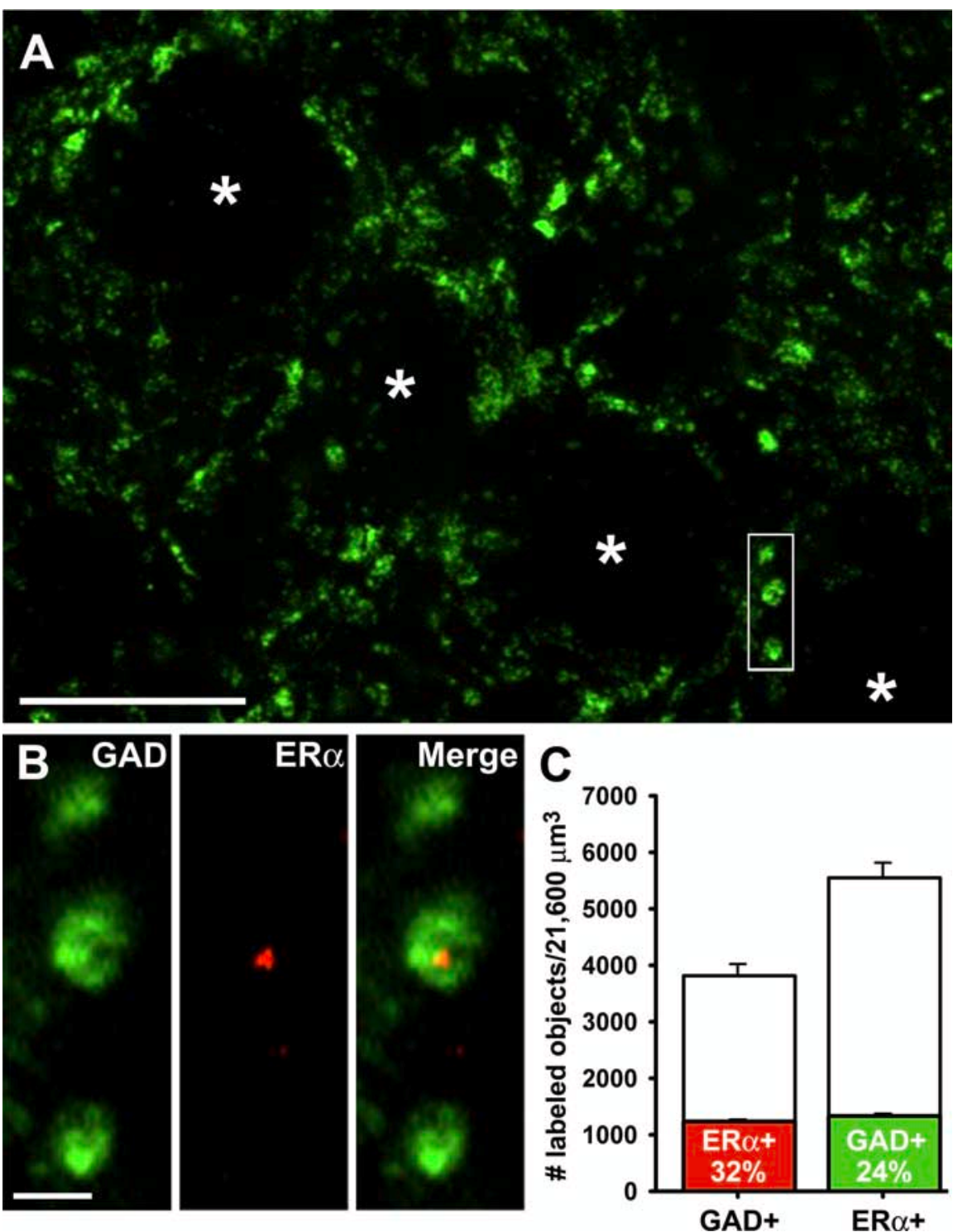

Figure 3. Colocalization of GAD-immunoreactive varicosities and $\mathrm{ER} \alpha$-immunoreactive puncta. $\boldsymbol{A}, \mathrm{A} 2$ - $\mu$ m-thick image stack (ER $\alpha$-IR) per $4 \mu \mathrm{m}$ stack of optical sections (21,600 $\mathrm{mm}^{3}$ volume); the colored portion of each bar represents the average number and percentage of varicosities or puncta that are double labeled. Error bars indicate SEM. Scale bars: $\boldsymbol{A}, 10 \mu \mathrm{m} ; \boldsymbol{B}, 1 \mu \mathrm{m}$.

not differ between OVX $+\mathrm{O}$ and $\mathrm{OVX}+\mathrm{E}$ boutons. It should be noted that because the $\mathrm{DAB}$ reaction product is diffusible up to $\sim 100 \mathrm{~nm}$ (Courtoy et al., 1983), it is possible that our measurement of $10.7 \%$ vesicles per bouton overestimates the true number of $\mathrm{ER} \alpha$-containing vesicles. Interestingly, patches of $\mathrm{ER} \alpha$-IR on the bouton plasma membrane were strongly associated with the presence of ER $\alpha$-immunoreactive vesicles; we found only one bouton that lacked labeled vesicles and showed any detectable ER $\alpha$-IR at the plasma membrane. None of the basic structural features of individual boutons (volume, presynaptic density area, single vs multiple synapses, presence of mitochondria, total vesicle number or vesicle density) was different between boutons that contained $\mathrm{ER} \alpha$-immunoreactive clusters and those that did not, and none of these parameters was affected by estrogen treatment (Table 1). 


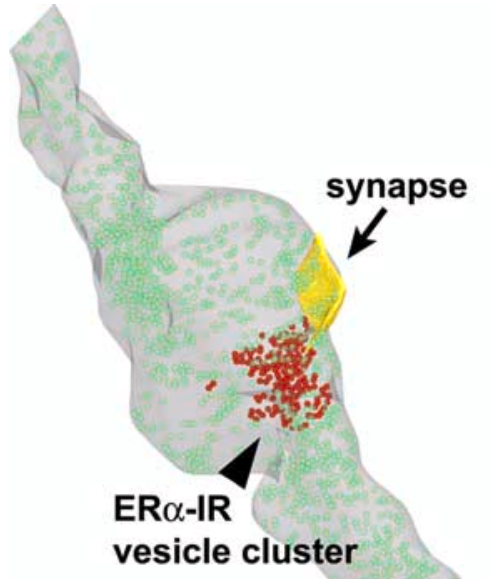

Figure 4. Three-dimensional reconstruction of an axon segment containing ER $\alpha$ immunoreactive vesicles. An axon segment from an estradiol-treated animal reconstructed through 80 serial sections shows two boutons that form perisomatic inhibitory synapses (yellow) with a CA1 pyramidal cell. Only one of the boutons contains a cluster of ER $\alpha$ immunoreactive vesicles (red). Green, Non-ER $\alpha$-immunoreactive vesicles; gray, bouton plasma membrane.

Although the basic structural features of $\mathrm{ER} \alpha$ immunoreactive-containing boutons did not differ between $\mathrm{OVX}+\mathrm{O}$ and $\mathrm{OVX}+\mathrm{E}$ animals, plotting the location of presynaptic vesicles within each bouton revealed a striking effect of estrogen to shift the location of $\mathrm{ER} \alpha$-immunoreactive vesicle clusters closer to synapses (Fig. 5A,B). Because axonal boutons vary widely by size, we determined the proximity of presynaptic vesicles to synapses using a relative distance measurement. For each bouton, the distance between each presynaptic vesicle and the nearest synapse was measured and converted to a value between 0 and 1.0 , with 1.0 being the maximum distance that a vesicle could be from the synapse. Comparison of histograms of relative distances in the 33 completely reconstructed boutons that contained $\mathrm{ER} \alpha$-IR (Fig. $5 C, D$, filled bars) showed that labeled vesicle clusters were located significantly closer to the nearest synapse in OVX + E compared with OVX + O boutons $(n=13$ OVX $+\mathrm{O} ; n=20$ OVX $+\mathrm{E} ; \mathrm{K}-\mathrm{S}$ test, $p<0.01$ ) (Fig. $5 D$, inset). Comparison of the mean relative distances on a per animal basis confirmed that estrogen decreased the distance between ER $\alpha$ immunoreactive vesicles and the nearest synapse by approximately one-half ( $n=4$; unpaired, two-tailed, Student's $t$ test, $p=$ 0.03 ). Additionally, although initial inspection of the histograms showing relative distances of unlabeled vesicles in OVX $+\mathrm{O}$ and $\mathrm{OVX}+\mathrm{E}$ boutons (Fig. $5 C, D$, open bars) suggested that they also
A side views end views
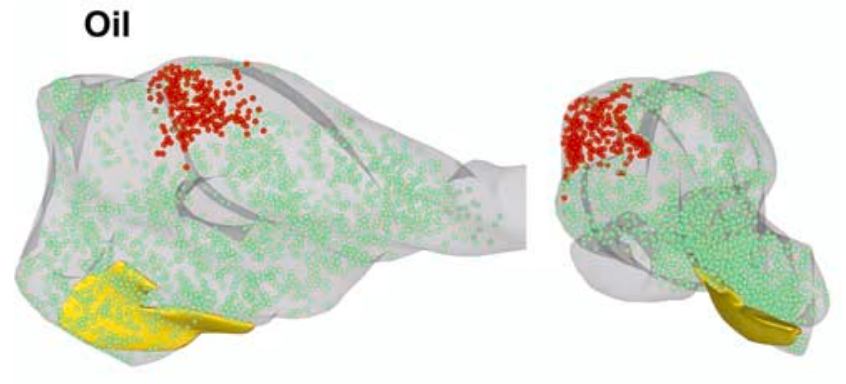

\section{B Estradiol}
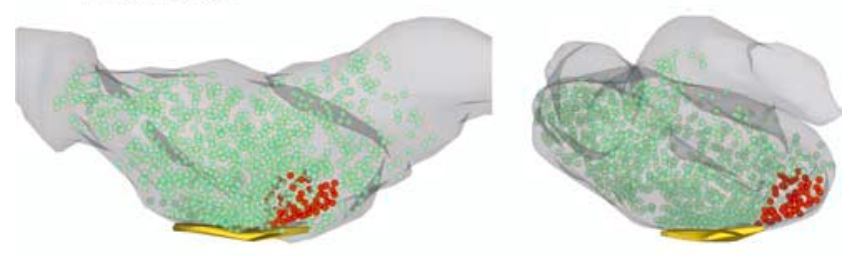

C
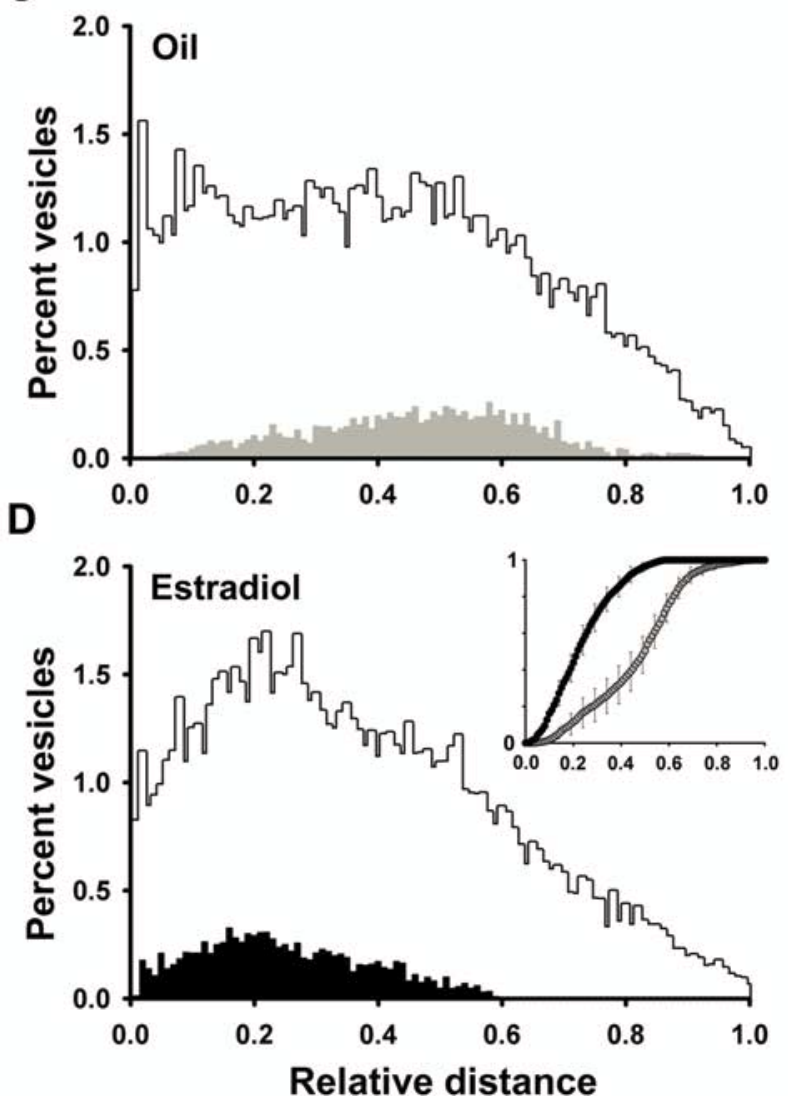

Figure 5. Three-dimensional reconstructions and vesicle distances in perisomatic inhibitory boutons containing $E R \alpha$-immunoreactive vesicle clusters. $A, B$, Side and end views (rotated by $90^{\circ}$ ) of reconstructed boutons from an oil-treated $(\boldsymbol{A})$ and an estradiol-treated $(\boldsymbol{B})$ animal showing that $E R \alpha$-immunoreactive vesicle clusters (red) are located closer to the synapse (yellow) in the bouton from an estrogen-treated animal (green, non-ER $\alpha$-immunoreactive vesicles; gray, bouton plasma membrane). $\boldsymbol{C}, \boldsymbol{D}$, Histograms showing the relative distance from the synapse of vesicles in reconstructed boutons containing $E R \alpha$-immunoreactive clusters in oil-treated ( $C$ ) and estradiol-treated $(\boldsymbol{D})$ animals. Distributions of $\mathrm{ER} \alpha$-immunoreactive vesicles are represented with filled bars (gray, oil; black, estradiol), whereas the distribution of non-ER $\alpha$ immunoreactive vesicles are represented by open bars. The inset in $\boldsymbol{D}$ shows cumulative histograms of the relative distances of ER $\alpha$-immunoreactive vesicles in oil (gray) and estradiol (black) animals demonstrating that labeled vesicles are located significantly closer to synapses after estrogen treatment (K-S test, $p<0.01$ ). 
Table 1. Structural characteristics of reconstructed perisomatic inhibitory boutons in the dorsal CA1 cell body layer

\begin{tabular}{|c|c|c|c|c|}
\hline \multirow[b]{2}{*}{ Bouton structural parameter } & \multicolumn{2}{|l|}{ Oil treated } & \multicolumn{2}{|l|}{ Estradiol treated } \\
\hline & $\mathrm{ER} \alpha+(n=4)$ & $\mathrm{ER} \alpha-(n=4)$ & $\mathrm{ER} \alpha+(n=4)$ & $\mathrm{ER} \alpha-(n=4)$ \\
\hline Volume $\left(\mu \mathrm{m}^{3}\right)$ & $0.44 \pm 0.11$ & $0.45 \pm 0.08$ & $0.49 \pm 0.06$ & $0.46 \pm 0.07$ \\
\hline Presynaptic density area $\left(\mu \mathrm{m}^{2}\right)$ & $0.08 \pm 0.02$ & $0.09 \pm 0.02$ & $0.08 \pm 0.01$ & $0.09 \pm 0.01$ \\
\hline Boutons with multiple synapses (\%) & $56 \pm 21$ & $64 \pm 8$ & $51 \pm 11$ & $63 \pm 5$ \\
\hline Boutons containing mitochondria (\%) & $100 \pm 0$ & $89 \pm 7$ & $88 \pm 7$ & $87 \pm 4$ \\
\hline Total number of vesicles & $1891 \pm 144$ & $2245 \pm 144$ & $2325 \pm 324$ & $2950 \pm 729$ \\
\hline Vesicle density $\left(\# / \mu \mathrm{m}^{3}\right)$ & $4882 \pm 685$ & $5676 \pm 764$ & $5104 \pm 611$ & $6298 \pm 780$ \\
\hline
\end{tabular}

The mean ( \pm SEM) for each parameter is shown both for boutons with $(E R \alpha+)$ and without (ER $\alpha-)$ ER $\alpha$-immunoreactive vesicle clusters from oil- and estradiol-treated animals. Neither ER $\alpha$-IR content nor estrogen treatmen significantly affected any parameter measured.

might be affected by estrogen, no significant difference or trend was detected (K-S test, $p>0.20$ ). Thus, the effect of estrogen to shift the location of presynaptic vesicles is specific for those that are $\operatorname{ER} \alpha$ immunoreactive. The observation that estrogen regulates the location of labeled vesicle clusters relative to synapses argues strongly that $\mathrm{ER} \alpha$-IR on vesicles is either $\mathrm{ER} \alpha$ itself or a very closely related protein. These appear to be a specific subset of presynaptic vesicles that, because they contain $\operatorname{ER} \alpha$, are regulated by estrogen separately from other presynaptic vesicles in the same bouton.

\section{Colocalization of extranuclear ER $\alpha$-IR with PV- or CCK-IR}

The perisomatic inhibitory boutons we reconstructed arise from basket cells, a population of GABAergic neurons that can be divided into two subtypes based on PV or CCK immunolabeling, each of which has distinct physiological roles in the hippocampus (Freund and Buzsaki, 1996; Freund, 2003). To determine whether $\mathrm{ER} \alpha$-IR is located specifically in one class of basket cell, we used double-label immunofluorescence to quantify colocalization of ER $\alpha$-IR with PV- or CCK-IR in the cell body layer in five $\mathrm{OVX}+\mathrm{O}$ and five $\mathrm{OVX}+\mathrm{E}$ animals. Estrogen treatment did not affect any parameter of PV-IR, CCK-IR, or colocalization, so data from both groups were combined $(n=10)$. Tissue double labeled for PV and $\mathrm{ER} \alpha$ showed the characteristic "beads on a string" PV staining of axons and axonal varicosities, but there was no colocalization of ER $\alpha$-IR and PV-IR (Fig. 6A). In contrast, ER $\alpha$-IR did colocalize with CCK-IR, which labels in a more punctate pattern (Morales and Bloom, 1997) than GAD or PV (Fig. 6B). Quantitative analysis of 18 image stacks per brain $\left(10,800 \mu \mathrm{m}^{3}\right.$ per stack) showed that $25.2 \pm 0.6 \%$ of $3817 \pm 177$ CCK-immunoreactive puncta per stack colocalized with ER $\alpha$-IR and $36.2 \pm 0.8 \%$ of $2762 \pm 72 \mathrm{ER} \alpha$-immunoreactive puncta per stack colocalized with CCK-IR (Fig. $6 E$ ). Thus, the axonal boutons containing $\mathrm{ER} \alpha$-immunoreactive vesicle clusters that we analyzed with serial-section EM likely belong to CCK basket cells and not PV basket cells.

Because the number of CCK-immunoreactive puncta was greater than the number of GAD-immunoreactive varicosities in the same volume, either there are multiple CCK-immunoreactive puncta per varicosity and/or some CCK-immunoreactive puncta are located in structures other than GABAergic varicosities. Consistent with the second possibility, CCK labeling has been shown previously in dendrites in CA1 (Harris et al., 1985; Morales and Bloom, 1997). The number of ER $\alpha / C C K$-immunoreactive structures per stack was $902 \pm 42$, which is similar to the number of $\mathrm{ER} \alpha / \mathrm{GAD}$-immunoreactive structures calculated for the same volume, $624 \pm 31$. Thus, most of the puncta that colocalize $\mathrm{ER} \alpha$-IR and CCK-IR are likely to be in GABAergic boutons.

\section{Colocalization of extranuclear ER $\alpha$-IR with NPY-IR}

A subset of GABAergic neurons in CA1 also expresses NPY (Freund and Buzsaki, 1996), and some NPY neurons express nuclear ER $\alpha$ (Sar et al., 1990), suggesting that extranuclear $\mathrm{ER} \alpha$-IR also might be found in NPY neurons. To investigate this, we analyzed colocalization of ER $\alpha$-IR and NPY-IR in the same tissue used for PV and CCK analyses. No measure of immunofluorescence or colocalization was affected by estrogen treatment, so data from both groups were combined $(n=10)$. Quantitative analysis of ER $\alpha$-IR and NPY-IR in the cell body layer (Fig. $6 C)$ showed that $30.3 \pm 0.6 \%$ of $4165 \pm 170$ NPYimmunoreactive puncta colocalized with $\mathrm{ER} \alpha$-IR and $49.9 \pm$ $2.2 \%$ of $2662 \pm 44 \mathrm{ER} \alpha$-immunoreactive puncta colocalized with NPY-IR (Fig. 6E).

The number of ER $\alpha / \mathrm{NPY}$-immunoreactive objects was greater than the number of $\mathrm{ER} \alpha / \mathrm{GAD}$-immunoreactive objects in the same volume, which suggested that a substantial fraction of ER $\alpha$ /NPY-IR might not be GABAergic. Thus, we performed an additional experiment to quantify NPY/GAD colocalization (Fig. $6 D$ ) and found that $\sim 73 \%$ of NPY-immunoreactive puncta in the cell body layer colocalized with GAD (data not shown). The remaining $\sim 27 \%$ of NPY-immunoreactive puncta likely belong to dendrites, excitatory boutons, or cytoplasmic organelles (Milner and Veznedaroglu, 1992; V. A. Ledoux and C. S. Woolley unpublished observations). Interestingly, the number of ER $\alpha$ immunoreactive puncta per stack that colocalized with NPY-IR $(\sim 1250)$ is very similar to the number of NPY-immunoreactive puncta that were negative for GAD $(\sim 1125)$. It is therefore possible that many $\mathrm{ER} \alpha / \mathrm{NPY}$-immunoreactive puncta are not located in GABAergic boutons.

\section{Discussion}

We used serial-section EM immunocytochemistry, cell fractionation, and immunofluorescence to show that $\operatorname{ER} \alpha$ is associated with clusters of vesicles in inhibitory presynaptic boutons in the hippocampal CA1 cell body layer and that estrogen treatment shifts the location of these vesicles toward synapses. ER $\alpha$ immunoreactive vesicle clusters are abundant, occurring in approximately one-third of perisomatic GABAergic boutons, but only in a subset of those on a single axon. Extranuclear ER $\alpha$-IR colocalizes with CCK and NPY, but not with PV, indicating that different neurochemical classes of GABA neurons are likely to be differentially sensitive to estrogen through $\mathrm{ER} \alpha$ located in presynaptic boutons. Our findings point to a novel mode of estrogen action in the brain in which estrogen acts directly on a subset of $\mathrm{ER} \alpha$-containing vesicles to mobilize them toward synapses.

\section{$\mathrm{ER} \boldsymbol{\alpha}$-immunoreactive vesicles}

ER $\alpha$-immunoreactive vesicles may contain GABA and undergo exocytosis to release neurotransmitter. Labeled vesicles in perisomatic boutons were small clear vesicles that were morphologically indistinguishable from unlabeled ones. We did occasionally observe $\mathrm{ER} \alpha$-IR associated with presynaptic densities, suggesting 

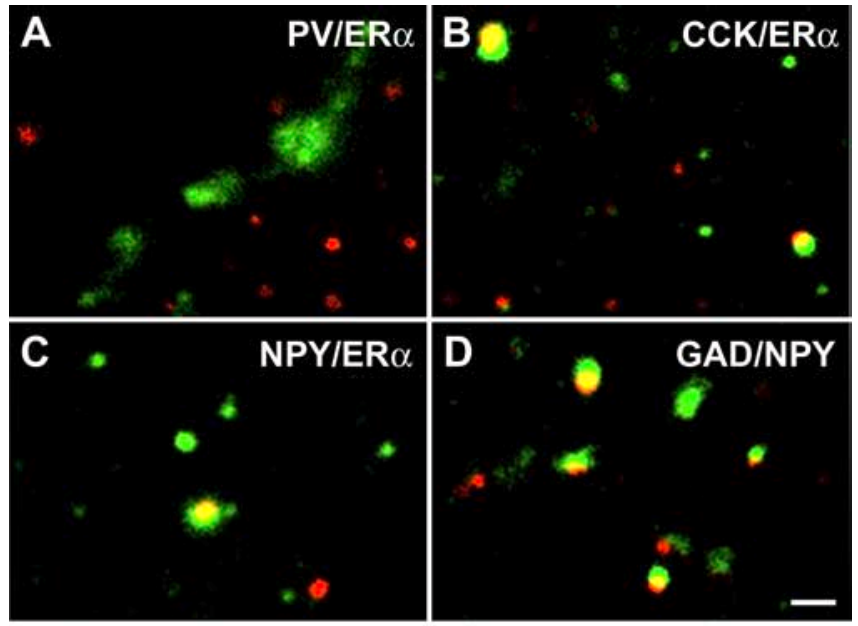

E

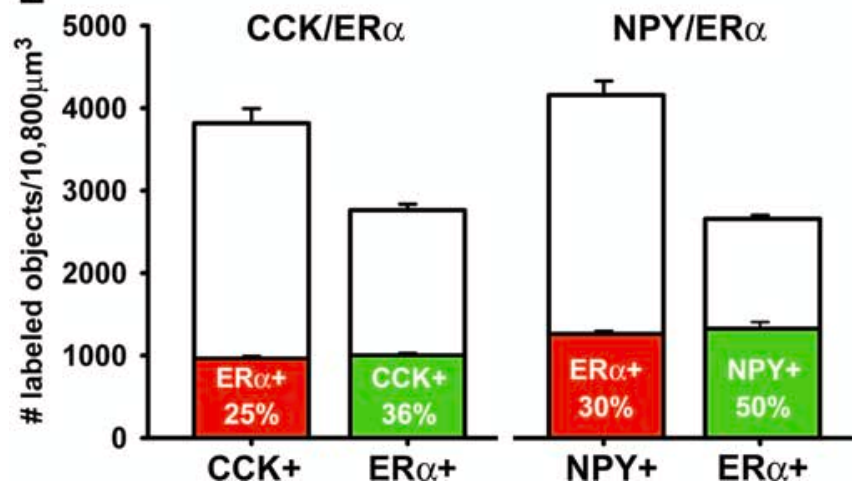

Figure 6. Colocalization of PV-, CCK-, and NPY-IR with extranuclear ER $\alpha$-IR. $\boldsymbol{A}$, ER $\alpha$ immunoreactive puncta (red) did not colocalize with PV-immunoreactive structures (green). $\boldsymbol{B}$, Some ER $\alpha$-immunoreactive puncta (red) did colocalize (yellow) with CCK-immunoreactive puncta (green). C, Some ER $\alpha$-immunoreactive puncta (red) also colocalized (yellow) with NPY-IR (green). $\boldsymbol{D}$, The majority ( $\sim 73 \%$ ) of NPY-immunoreactive puncta (red) are colocalized (yellow) with GAD-IR (green). E, Quantification of CCK- and NPY-IR with ER $\alpha$-IR. The entire height of each bar represents the average total number of labeled puncta per $2 \mu \mathrm{m}$ stack of optical sections (10,800 $\mu \mathrm{m}^{3}$ volume); the colored portion of each bar represents the average number and percentage of puncta that were double labeled. Error bars indicate SEM. Scale bar, $1 \mu \mathrm{m}$.

fusion at synaptic active zones. If $\mathrm{ER} \alpha$-immunoreactive vesicles function to release neurotransmitter, then our results indicate a specialized subpopulation of GABAergic vesicles within individual presynaptic boutons that is regulated independently of the others (i.e., by estrogen). If this is the case, then the simplest interpretation of the estrogen-induced mobilization of labeled vesicles is that it reflects their movement toward synaptic release sites. Mobilization of ER $\alpha$-immunoreactive vesicles toward synapses may influence the sensitivity of hippocampal synapses to acute estrogen action.

It is important to note that this effect to mobilize $\operatorname{ER} \alpha$ immunoreactive vesicles toward synapses is distinct from our previous observations that $24 \mathrm{~h}$ estrogen treatment suppresses GABA release (Rudick et al., 2003) and decreases the number of vesicles docked at GABAergic synapses (Ledoux and Woolley, 2005). Our previous studies did not distinguish between boutons and/or vesicles that contain $\mathrm{ER} \alpha$ and those that do not and focused specifically on docked vesicles that are much closer to presynaptic release sites than the vast majority of ER $\alpha$ immunoreactive vesicles. Thus, the observation that estrogen mobilizes specifically $\mathrm{ER} \alpha$-immunoreactive vesicles toward synapses is further evidence that $\mathrm{ER} \alpha$ confers specialized estrogen sensitivity to a distinct subset of vesicles in inhibitory boutons.
In addition to the possibility that $\mathrm{ER} \alpha$-immunoreactive vesicles are neurotransmitter vesicles, an alternative is that ER $\alpha$ immunoreactive vesicles are specialized endosomes that deliver $\mathrm{ER} \alpha$ to, and/or retrieve it from, the bouton plasma membrane. Patches of ER $\alpha$-IR at the bouton membrane, usually near labeled vesicle clusters, are consistent with this idea. Studies in a variety of cell types have demonstrated $\mathrm{ER} \alpha$ at the plasma membrane where it functions as a G-protein-coupled receptor (Razandi et al., 1999; Wyckoff et al., 2001) and can influence secretion of neuropeptides (Navarro et al., 2003). If ER $\alpha$-immunoreactive vesicles are involved in regulating membrane-associated $\mathrm{ER} \alpha$, then estrogen effects on ER $\alpha$-immunoreactive vesicle location could result from exocytosis and/or endocytosis at different sites relative to synapses. Interestingly, however, we found that the number of vesicles per ER $\alpha$-immunoreactive cluster was not affected by estrogen, arguing against the idea that estrogen specifically stimulates $\mathrm{ER} \alpha$ delivery to or retrieval from the plasma membrane.

$\mathrm{ER} \alpha$ contains neither a known membrane targeting sequence nor stretches of hydrophobic residues characteristic of an integral membrane protein; however, in breast cancer cells and Chinese hamster ovary cells, $\mathrm{ER} \alpha$ has been shown to associate with caveolin-1, which facilitates its transport to the membrane (Razandi et al., 2003). In these cells, membrane ER $\alpha$ forms a signaling complex with other proteins through which estrogen can rapidly increase cAMP and activate mitogen-activated protein kinase (MAPK) and phosphatidylinositol-3 kinase (PI3K) (for review, see Levin, 2005). This requires dimerizationcompetent $\mathrm{ER} \alpha$ and involves the ligand-binding and AF2 domains (Razandi et al., 2004). Similar rapid signaling through MAPK and PI3K also occurs in neurons (Bryant et al., 2005; Mannella and Brinton, 2006). Mobilization of ER $\alpha$-containing vesicles could influence synaptic function by bringing an estrogen-sensitive rapid signaling complex nearer to synaptic release sites.

The ability of membrane-associated $\operatorname{ER} \alpha$ to activate MAPK could provide a link between rapid estrogen signaling and our previous observation that estrogen decreases the number of vesicles docked at GABAergic synapses. Estrogen acutely activates MAPK in hippocampal neurons (Bi et al., 2000), possibly through a membrane ER (Kuroki et al., 2000). One substrate for MAPK in presynaptic boutons is synapsin-I, which anchors synaptic vesicles to the actin cytoskeleton in a phosphorylationdependent manner (Jovanovic et al., 1996). Phosphorylation of synapsin-I at MAPK sites is involved in mobilization of synaptic vesicles for release (Chi et al., 2003), and at inhibitory synapses, synapsins are critical for maintaining the readily releasable pool of vesicles (Gitler et al., 2004). As mentioned above, we have shown previously that estrogen suppresses GABA release in CA1, at least in part by decreasing the number of vesicles docked at inhibitory synapses. Therefore, it is tempting to speculate that $\mathrm{ER} \alpha$ signaling in inhibitory boutons could mediate the estrogeninduced decrease in docked vesicle number through regulation of MAPK and synapsin phosphorylation.

\section{Colocalization of ER $\alpha$ and CCK}

The finding that extranuclear ER $\alpha$-IR colocalizes with CCK, but not PV, indicates that direct effects of estrogen on presynaptic boutons likely occur only in the CCK subtype of the basket cell. This is significant because PV and CCK cells differ in their electrophysiological and anatomical properties and their influence on pyramidal cells. Most PV basket cells are capable of firing at high frequencies without accommodation and release GABA synchronously; CCK cells fire at lower frequencies, do show accom- 
modation, and release GABA asynchronously (Pawelzik et al., 2002; Hefft and Jonas, 2005). These and other findings (Klausberger et al., 2003; Vreugdenhil et al., 2003) have been interpreted to indicate that PV cells play a greater role than CCK cells in entraining rhythmic activity of pyramidal cells, particularly at gamma frequency (Freund, 2003).

Additionally, anatomical studies show that $\mathrm{PV}$ cells receive, on average, $\sim 15,000$ excitatory and $\sim 1000$ inhibitory inputs (Gulyas et al., 1999), whereas CCK cells receive only $\sim 5000$ excitatory but $\sim 3000$ inhibitory inputs (Matyas et al., 2004). CCK cells also receive GABAergic input from a specialized, interneuron-driven population of calretinin-positive neurons (Gulyas et al., 1996) and serotonergic input from the median raphe, neither of which innervate PV cells (Miettinen and Freund, 1992; Morales and Bloom, 1997). Thus, PV and CCK cells appear to monitor the activities of different populations of neurons, and CCK cells are in a better position to respond to modulatory GABAergic and serotonergic inputs. These differences have led to the hypothesis that relatively nonplastic ensembles of PV basket cells are responsible for synchronizing the activity of pyramidal cells, whereas more modifiable groups of CCK basket cells integrate local and subcortical inputs to fine-tune pyramidal cell activity (Freund, 2003). The colocalization of ER $\alpha$-IR with CCK- but not PV-IR suggests that estrogen could act through ER $\alpha$ in CCK basket cell axonal boutons to influence such fine-tuning of hippocampal activity.

\section{Colocalization of ER $\alpha$ and NPY}

The colocalization of ER $\alpha$-IR with NPY-IR provides an additional clue to the role of extranuclear $\mathrm{ER} \alpha$ in the hippocampus. In CA1, NPY is expressed primarily in GABAergic interneurons (Freund and Buzsaki, 1996) but also is expressed within excitatory neurons (Milner and Veznedaroglu, 1992). NPY inhibits presynaptic glutamate release in the hippocampus (Colmers et al., 1988), and in cortical synaptosomes, this occurs through a Y1 receptor-dependent reduction in $\mathrm{Ca}^{2+}$ influx through $\mathrm{N}$ - and/or $\mathrm{P} / \mathrm{Q}$-type $\mathrm{Ca}^{2+}$ channels (Wang, 2005). Although it is likely that $\mathrm{ER} \alpha / \mathrm{NPY}$ sites in the CA1 cell body layer are located too far from most glutamatergic inputs to influence them, it is possible that a similar mechanism could regulate GABA release at perisomatic synapses. Calcium-dependent GABA release in CA1 also depends on $\mathrm{N}$ - and/or P/Q-type $\mathrm{Ca}^{2+}$ channels (Doze et al., 1995). Additionally, NPY has been shown to suppress GABAergic synaptic transmission in the spinal cord (Moran et al., 2004) and paraventricular nucleus (Pronchuk et al., 2002), and at least some GABAergic neurons express Y1 receptors (Oberto et al., 2001). Thus, sites at which ER $\alpha$ and NPY are colocalized, whether in inhibitory boutons or other structures, could provide an additional means by which estrogen suppresses GABAergic synaptic transmission, in this case by modulating the release of NPY.

In summary, quantitative analysis of $\mathrm{ER} \alpha$ in perisomatic inhibitory boutons demonstrates a novel mode of estrogen action in the brain, to mobilize a specific subset of vesicles that contain $\mathrm{ER} \alpha$. In the CA1 cell body layer, these vesicles occur selectively in one class of basket cell, CCK cells, where they may be a subset of neurotransmitter vesicles and/or may be involved in regulating $\mathrm{ER} \alpha$ at the bouton plasma membrane. Estrogen previously has been shown to have profound effects on inhibitory synapses in CA1 that are likely to be causally related to a subsequent increase in excitatory synapse number. The current study represents an initial step toward understanding how estrogen could act through extranuclear receptors associated with a specific subcellular compartment, presynaptic vesicles, to influence neuronal function. Direct effects of estrogen on presynaptic boutons may provide a link between rapid estrogen signaling (e.g., through modulation of protein kinase activity) and the longer-term effects of estrogen on synaptic structure and function.

\section{References}

Acconcia F, Ascenzi P, Bocedi A, Spisni E, Tomasi V, Trentalance A, Visca P, Marino M (2005) Palmitoylation-dependent estrogen receptor alpha membrane localization: regulation by 17beta-estradiol. Mol Biol Cell 16:231-237.

Adams MM, Shah RA, Janssen WG, Morrison JH (2001) Different modes of hippocampal plasticity in response to estrogen in young and aged female rats. Proc Natl Acad Sci USA 98:8071-8076.

Azcoitia I, Sierra A, Garcia-Segura LM (1999) Localization of estrogen receptor $\beta$-immunoreactivity in astrocytes of the adult rat brain. Glia 26:260-267.

Bevitt DJ, Milton ID, Piggot N, Henry L, Carter MJ, Toms GL, Lennard TW, Westley B, Angus B, Horne CH (1997) New monoclonal antibodies to oestrogen and progesterone receptors effective for paraffin section immunohistochemistry. J Pathol 183:228-232.

Bi R, Broutman G, Foy M, Thompson RF, Baudry M (2000) The tyrosine kinase and MAP kinase pathways mediate multiple effects of estrogen in hippocampus. Proc Natl Acad Sci USA 97:3602-3607.

Blaustein JD, Lehman MN, Turcotte JC, Greene G (1992) Estrogen receptors in dendrites and axon terminals in the guinea pig hypothalamus. Endocrinology 131:281-290.

Blurton-Jones M, Tuszynski MH (2002) Estrogen receptor-beta colocalizes extensively with parvalbumin-labeled inhibitory neurons in the cortex, amygdala, basal forebrain, and hippocampal formation of intact and ovariectomized adult rats. J Comp Neurol 452:276-287.

Bryant DN, Bosch MA, Ronnekleiv OK, Dorsa DM (2005) 17-Beta estradiol rapidly enhances extracellular signal-regulated kinase 2 phosphorylation in the rat brain. Neuroscience 133:343-352.

Chi P, Greengard P, Ryan TA (2003) Synaptic vesicle mobilization is regulated by distinct synapsin I phosphorylation pathways at different frequencies. Neuron 38:69-78.

Colmers WF, Lukowiak K, Pittman QJ (1988) Neuropeptide Y action in the rat hippocampal slice: site and mechanism of presynaptic inhibition. J Neurosci 8:3827-3837.

Courtoy PJ, Picton DH, Farquar MG (1983) Resolution of limitations of the immunoperoxidase procedure in the localization of extracellular matrix proteins. J Histochem Cytochem 31:945-951.

Doze VA, Cohen GA, Madison DV (1995) Calcium channel involvement in $\mathrm{GABA}_{\mathrm{B}}$ receptor-mediated inhibition of GABA release in area CA1 of the rat hippocampus. J Neurophysiol 74:43-53.

Freund TF (2003) Interneuron diversity series: rhythm and mood in perisomatic inhibition. Trends Neurosci 26:489-495.

Freund TF, Buzsaki G (1996) Interneurons of the hippocampus. Hippocampus 6:347-470.

Gitler D, Takagishi Y, Feng J, Ren Y, Rodriguiz RM, Wetsel WC, Greengard P, Augustine GJ (2004) Different presynaptic roles of synapsins at excitatory and inhibitory synapses. J Neurosci 24:11368-11380.

Greene GL, Gilna P, Waterfield M, Baker A, Hort Y, Shine J (1986) Sequence and expression of human estrogen receptor complementary DNA. Science 231:1150-1154.

Gulyas AI, Hajos N, Freund TF (1996) Interneurons containing calretinin are specialized to control other interneurons in the rat hippocampus. J Neurosci 16:3397-3411.

Gulyas AI, Megias M, Emri Z, Freund TF (1999) Total number and ratio of excitatory and inhibitory synapses converging onto single interneurons of different types in the CA1 area of the rat hippocampus. J Neurosci 19:10082-10097.

Harris KM, Marshall PE, Landis DM (1985) Ultrastructural study of cholecystokinin-immunoreactive cells and processes in area CA1 of the rat hippocampus. J Comp Neurol 233:147-158.

Hart SA, Patton JD, Woolley CS (2001) Quantitative analysis of ER $\alpha$ and GAD colocalization in the hippocampus of the adult female rat. J Comp Neurol 440:144-155.

Hefft S, Jonas P (2005) Asynchronous GABA release generates long-lasting inhibition at a hippocampal interneuron-principal neuron synapse. Nat Neurosci 8:1319-1328.

Huttner WB, Schiebler W, Greengard P, De Camilli P (1983) Synapsin I (protein I), a nerve terminal-specific phosphoprotein. III. Its association 
with synaptic vesicles studied in a highly purified synaptic vesicle preparation. J Cell Biol 96:1374-1388.

Jovanovic JN, Benfenati F, Siow YL, Sihra TS, Sanghera JS, Pelech SL, Greengard P, Czernik AJ (1996) Neurotrophins stimulate phosphorylation of synapsin I by MAP kinase and regulate synapsin I-actin interactions. Proc Natl Acad Sci USA 93:3679-3683.

Klausberger T, Magill PJ, Marton LF, Roberts JD, Cobden PM, Buzsaki G, Somogyi P (2003) Brain-state- and cell-type-specific firing of hippocampal interneurons in vivo. Nature 421:844-848.

Koike S, Sakai M, Muramatsu M (1987) Molecular cloning and characterization of the rat estrogen receptor cDNA. Nucleic Acids Res 15:2499-2513.

Kuiper GG, Enmark E, Pelto-Huikko M, Nilsson S, Gustafsson JA (1996) Cloning of a novel receptor expressed in rat prostate and ovary. Proc Natl Acad Sci USA 93:5925-5930.

Kuroki Y, Fukushima K, Kanda Y, Mizuno K, Watanabe Y (2000) Putative membrane-bound estrogen receptors possibly stimulate mitogen-activated protein kinase in the rat hippocampus. Eur J Pharmacol 400:205-209.

Ledoux VA, Woolley CS (2005) Evidence that disinhibition is associated with a decrease in number of vesicles available for release at inhibitory synapses. J Neurosci 25:971-976.

Leenen PJM, Jansen AMAC, Ewijk WV (1985) Fixation parameters for immunocytochemistry: the effect of glutaraldehyde or paraformaldehyde fixation on the preservation of mononuclear phagocyte differentiation antigens. In: Techniques in immunocytochemistry, Vol 3 (Bullock GR, Petrusz P, eds), pp 1-24. New York: Academic.

Levin ER (2005) Integration of the extranuclear and nuclear actions of estrogen. Mol Endocrinol 19:1951-1959.

Mannella P, Brinton RD (2006) Estrogen receptor protein interaction with phosphatidylinositol 3-kinase leads to activation of phosphorylated Akt and extracellular signal-regulated kinase $1 / 2$ in the same population of cortical neurons: a unified mechanism of estrogen action. J Neurosci 26:9439-9447.

Matyas F, Freund TF, Gulyas AI (2004) Convergence of excitatory and inhibitory inputs onto CCK-containing basket cells in the CA1 area of the rat hippocampus. Eur J Neurosci 19:1243-1256.

Miettinen R, Freund TF (1992) Convergence and segregation of septal and median raphe inputs onto different subsets of hippocampal inhibitory interneurons. Brain Res 594:263-272.

Milner TA, Veznedaroglu E (1992) Ultrastructural localization of neuropeptide Y-like immunoreactivity in the rat hippocampal formation. Hippocampus 2:107-126

Milner TA, McEwen BS, Hayashi S, Li CJ, Reagan LP, Alves SE (2001) Ultrastructural evidence that hippocampal alpha estrogen receptors are located at extranuclear sites. J Comp Neurol 429:355-371.

Mitra SW, Hoskin E, Yudkovitz J, Pear L, Wilkinson HA, Hayashi S, Pfaff DW, Ogawa S, Rohrer SP, Schaeffer JM, McEwen BS, Alves SE (2003) Immunolocalization of estrogen receptor $\beta$ in the mouse brain: comparison with estrogen receptor $\alpha$. Endocrinology 144:2055-2067.

Morales M, Bloom FE (1997) The 5- $\mathrm{HT}_{3}$ receptor is present in different subpopulations of GABAergic neurons in the rat telencephalon. J Neurosci 17:3157-3167.

Moran TD, Colmers WF, Smith PA (2004) Opioid-like actions of neuropeptide $\mathrm{Y}$ in rat substantia gelatinosa: $\mathrm{Y} 1$ suppression of inhibition and Y2 suppression of excitation. J Neurophysiol 92:3266-3275.

Murphy DD, Cole NB, Greenberger V, Segal M (1998) Estradiol increases dendritic spine density by reducing GABA neurotransmission in hippocampal neurons. J Neurosci 18:2550-2559.

Navarro CE, Abdul Saeed S, Murdock C, Martinez-Fuentes AJ, Arora KK, Krsmanovic LZ, Catt KJ (2003) Regulation of cyclic adenosine 3',5'monophosphate signaling and pulsatile neurosecretion by $\mathrm{G}_{\mathrm{i}}$-coupled plasma membrane estrogen receptors in immortalized gonadotropinreleasing hormone neurons. Mol Endocrinol 17:1792-1804.

Oberto A, Panzica GC, Altruda F, Eva C (2001) GABAergic and NPY-Y network in the medial amygdala: a neuroanatomical basis for their functional interaction. Neuropharmacology 41:639-642.

Pawelzik H, Hughes DI, Thomson AM (2002) Physiological and morphological diversity of immunocytochemically defined parvalbumin- and cholecystokinin-positive interneurones in CA1 of the adult rat hippocampus. J Comp Neurol 443:346-367.
Pronchuk N, Beck-Sickinger AG, Colmers WF (2002) Multiple NPY receptors inhibit $\mathrm{GABA}_{\mathrm{A}}$ synaptic responses of rat medial parvocellular effector neurons in the hypothalamic paraventricular nucleus. Endocrinology 143:535-543.

Qiu J, Bosch MA, Tobias SC, Krust A, Graham SM, Murphy SJ, Korach KS, Chambon P, Scanlan TS, Ronnekleiv OK, Kelly MJ (2006) A G-proteincoupled estrogen receptor is involved in hypothalamic control of energy homeostasis. J Neurosci 26:5649-5655.

Razandi M, Pedrum A, Greene GL, Levin ER (1999) Cell membrane and nuclear estrogen receptors (ERs) originate from a single transcript: studies of ER $\alpha$ and ER $\beta$ expressed in Chinese hamster ovary cells. Mol Endocrinol 13:307-319.

Razandi M, Alton G, Pedram A, Ghonshani S, Webb P, Levin ER (2003) Identification of a structural determinant necessary for the localization and function of estrogen receptor $\alpha$ at the plasma membrane. Mol Cell Biol 23:1633-1646.

Razandi M, Pedram A, Merchenthaler I, Greene GL, Levin ER (2004) Plasma membrane estrogen receptors exist and function as dimers. Mol Endocrinol 18:2854-2865.

Rudick CN, Woolley CS (2001) Estrogen regulates functional inhibition of hippocampal CA1 pyramidal cells in the adult female rat. J Neurosci 21:6532-6543

Rudick CN, Woolley CS (2003) Selective estrogen receptor modulators regulate phasic activation of hippocampal CA1 pyramidal cells by estrogen. Endocrinology 144:179-187.

Rudick CN, Gibbs RB, Woolley CS (2003) A role for the basal forebrain cholinergic system in estrogen-induced disinhibition of hippocampal pyramidal cells. J Neurosci 23:4479-4490.

Rune GM, Wehrenberg U, Prange-Kiel J, Zhou L, Adelmann G, Frotscher M (2002) Estrogen up-regulates estrogen receptor $\alpha$ and synaptophysin in slice cultures of rat hippocampus. Neuroscience 113:167-175.

Sar M, Sahu A, Crowley WR, Kalra SP (1990) Localization of neuropeptide-Y immunoreactivity in estradiol-concentrating cells in the hypothalamus. Endocrinology 127:2752-2756.

Shughrue PJ, Lane MV, Merchenthaler I (1997) Comparative distribution of estrogen receptor- $\alpha$ and $-\beta$ mRNA in the rat central nervous system. J Comp Neurol 388:507-525.

Terasawa E, Timiras PS (1968) Electrical activity during the estrous cycle of the rat: cyclic changes in limbic structures. Endocrinology 83:207-216.

Teyler TJ, Vardaris RM, Lewis D, Rawitch AB (1980) Gonadal steroids: Effects on excitability of hippocampal pyramidal cells. Science 209:1017-1019.

Vreugdenhil M, Jefferys JG, Celio MR, Schwaller B (2003) Parvalbumindeficiency facilitates repetitive IPSCs and gamma oscillations in the hippocampus. J Neurophysiol 89:1414-1422.

Wang SJ (2005) Activation of neuropeptide Y Y1 receptors inhibits glutamate release through reduction of voltage-dependent $\mathrm{Ca}(2+)$ entry in the rat cerebral cortex nerve terminals: suppression of this inhibitory effect by the protein kinase C-dependent facilitatory pathway. Neuroscience 134:987-1000.

West MJ, Slomianka L, Gundersen HJG (1991) Unbiased stereological estimation of the total number of neurons in the subdivisions of the rat hippocampus using the optical fractionator. Anat Rec 231:482-497.

Wong M, Moss RL (1992) Long-term and short-term electrophysiological effects of estrogen on the synaptic properties of hippocampal CA1 neurons. J Neurosci 12:3217-3225.

Woolley CS, McEwen BS (1992) Estradiol mediates fluctuation in hippocampal synapse density during the estrous cycle in the adult rat. J Neurosci 12:2549-2554.

Woolley CS, Weiland NG, McEwen BS, Schwartzkroin PA (1997) Estradiol increases the sensitivity of hippocampal CA1 pyramidal cells to NMDA receptor-mediated synaptic input: correlation with dendritic spine density. J Neurosci 17:1848-1859.

Wyckoff MH, Chambliss KL, Mineo C, Yuhanna IS, Mendelsohn ME, Mumby SM, Shaul PW (2001) Plasma membrane estrogen receptors are coupled to endothelial nitric-oxide synthase through $\mathrm{G} \alpha_{(\mathrm{i})}$. J Biol Chem 276:27071-27076. 